\title{
KESIAPAN GURU BAHASA INDONESIA SMP DALAM IMPLEMENTASI KURIKULUM 2013
}

\author{
Setyawan Pujiono \\ FBS Universitas Negeri Yogyakarta \\ e-mail: setya_one14@yahoo.com
}

\begin{abstract}
Abstrak
Penelitian ini bertujuan mendeskripsikan kesiapan guru SMP dalam implementasi Kurikulum 2013. Kesiapan tersebut mencakup pemahaman guru terhadap kurikulum, kemampuan menyiapkan perangkat pembelajaran, menyusun silabus, dan mengembangkan materi ajar. Jenis penelitian ini adalah deskriptif dengan pendekatan survei. Subjek penelitian ini adalah guru bahasa Indonesia SMP se-Kabupaten Kulonprogo. Pengumpulan data menggunakan angket, kemudian dianalisis secara deskriptif melalui kategorisasi berdasarkan karakteristik masing-masing. Hasil penelitian menujukkan bahwa guruguru bahasa Indonesia SMP siap menerapkan Kurikulum 2013. Kesiapan tersebut tampak pada: (1) pemahaman isi kurikulum $(68,91 \%)$, (2) kesiapan guru dalam perencanaan pembelajaran $(68,69 \%)$, (3) kesiapan guru dalam pelaksanaan pembelajaran $(72,67 \%)$, dan (4) pemahaman guru terhadap evaluasi dan ketuntasan belajar $(67,83 \%)$. Untuk meningkatkan kesiapan implementasi Kurikulum 2013 dilakukan dengan memperbanyak sosialisasi, memperkaya materi pendukung, dan pelatihan penyusunan rencana program pembelajaran (RPP).
\end{abstract}

Kata kunci: pembelajaran, Kurikulum 2013, silabus, implementasi

\section{THE READINESS OF INDONESIAN LANGUAGE TEACHERS AT JUNIOR HIGH SCHOOLS IN THE IMPLEMENTATION OF CURRICULUM 2013}

\begin{abstract}
This study aims to describe the readiness of teachers at junior high schools (JHSs) in the implementation of Curriculum 2013. The readiness comprises their understanding of the curriculum and abilities to prepare learning kits, design the syllabus, and develop learning materials. This was a descriptive study employing the survey approach. The research subjects were Indonesian language teachers at JHSs in Kulonprogo Regency. The data were collected through a questionnaire and were descriptively analyzed using categories based on each characteristic. The results show that Indonesian language teachers at JHSs are ready to implement Curriculum 2013. This is indicated by: (1) their understanding of the curriculum contents $(68.91 \%),(2)$ their readiness in lesson planning $(68.69 \%),(3)$ their readiness in learning implementation $(72.67 \%)$, and (4) their understanding of evaluation and learning mastery $(67.83 \%)$. The improvement of the readiness in the implementation of Curriculum 2013 is made through intensifying socialization, enriching supplementary materials, and attending training on lesson plan designs.
\end{abstract}

Keywords: learning, Curriculum 2013, syllabus, implementation 


\section{PENDAHULUAN}

Pendidikan merupakan upaya yang mendasar untuk proses pengembangan sumber daya manusia agar lebih berkualitas. Dunia pendidikan, khususnya pendidikan sekolah memegang peranan utama dalam pengembangan sumber daya manusia. Dalam konteks inilah, pendidikan akan semakin dituntut peranannya dalam menciptakan lulusan yang berkualitas. Oleh karena itu, pendidikan nasional harus diselenggarakan secara adil, merata, berkualitas, dan sesuai dengan perkembangan zaman.

Dalam UU RI No. 20 tahun 2003 tertulis bahwa tujuan pendidikan nasional adalah untuk mengembangkan peserta didik agar menjadi manusia yang bertakwa kepada Tuhan Yang Maha Esa, berakhlak mulia, sehat, berilmu, kreatif, mandiri, demokratis, dan bertanggung jawab. Tujuan pendidikan tersebut mencangkup tiga ranah berpikir yaitu ranah kognitif, psikomotorik dan afektif. Selanjutnya, ketiga ranah tersebut menjadi landasan dalam proses pembelajaran peserta didik serta sistem penilaiannya (Kemendikbud, 2013).

Tujuan pendidikan nasional akan terwujud, jika pelaksanaan pendidikan di tingkat sekolah (lembaga pendidikan) berjalan sesuai dengan perkembangan di masyarakat. Untuk itu, penyelenggara pendidikan perlu memperhatikan elemen-elemen utama di lingkungan pendidikan sekolah. Mulyasa (2003) menyebutkan elemen-elemen itu adalah sebagai berikut. Pertama, guru adalah pelaksana inti dalam proses pendidikan di sekolah yang berperan sebagai fasilitator transfer ilmu pengetahuan bagi siswa. Kedua, siswa adalah peserta didik yang mengikuti proses pembelajaran di sekolah dengan maksud meningkatkan kemampuan diri atau proses pendewasaan bagi peserta didik. Ketiga, sarana dan prasarana adalah seperangkat alat dan media untuk mendukung pelaksanaan pendidikan di sekolah, seperti perpustakan, laboratorium, ruang praktik, komputer, dan media pengajaran. Keempat, karyawan adalah staf bagian selain pengajar yang mendukung terlaksananya porses pendidikan di sekolah. Kelima, kurikulum adalahkeseluruhan kegiatan pembelajaran yang disusun dan dikembangkan oleh instansi pendidikan (sekolah) yang diperuntukkan untuk peserta didik yang meliputi tujuan, materi/ bahan, strategi dan evaluasi pembelajaran.

Meskipun kelima elemen di atas merupakan satu kesatuan yang menentukan keberhasilan dalam pendidikan, tetapi fokus penelitian ini pada kesiapan guru menerapkan kurikulum. Guru dan kurikulum mempunyai peran yang signifikan di dalam proses pembelajaran. Kurikulum tidak hanya dijadikan acuan dalam pembelajaran di sekolah, tetapi kualitas kurikulum merupakan faktor penentu keberhasilan pendidikan dan terciptanya lulusan yang berkualitas dan berakhlak. Begitu juga guru, sebaik apapun kurikulum jika tidak didukung dengan guru yang professional tujuan pendidikan tidak akan tercapai. Untuk itu, kadang guru dan kurikulum dianggap sebagai faktor penyebab gagalnya pendidikan sekolah karena rendahnya kualitas hasil, akhlak, dan prestasi pendidikan di lingkungan masyarakat.

Rendahnya kualitas sumber daya manusia dikarenakan rendahnya mutu pendidikan, sehingga upaya peningkatan mutu pendidikan baik secara formal maupun nonformal dalam rangka mencetak kualitas sumber daya manusia yang berkualitas mutlak dilakukan. Salah satu upaya peningkatan mutu pendidikan dengan cara pengembangan kurikulum. Salah satu hal yang mendasari pengembangan kurikulum 2013 adalah terkait dengan aspek relevansi dengan tingkat perkembangan peserta didik dan tingkat perkembangan zaman. 
Kurikulum bidang studi bahasa Indonesia, diasumsikan sebagai upaya perbaikan pembelajaran. Materi pokok bahasan dalam kurikulum pembelajaran bahasa Indonesia dilakukan melalui pendekatan yang terintegrasi (integrated curriculum) dengan mempertimbangkan kesinambungan antarkelas dan keharmonisan antarmata pelajaran yang diikat dengan kompetensi inti (Kemendikbud, 2013:3). Pengintegra-sian tersebut, memberikan kemudahan dan penyederhanaan untuk proses belajar mengajar.

Misi yang ingin dicapai, antara lain agar suatu lulusan dari jenjang pendidikan tertentu benar-benar memiliki kompetensi dan nilai-nilai yang dapat diukur atau diamati. Adapun yang dimaksud dengan istilah kompetensi adalah kemampuan yang harus dimiliki seorang peserta didik untuk setiap kelas melalui pembelajaran Kompetensi Dasar yang diorganisasikan dalam pembelajaran siswa aktif (Kemendikbud, 2013:4). Berkaitan dengan kompetensi ini jelas kemampuan yang dituntut dari suatu lulusan adalah meliputi ranah kognitif, psikomotorik dan afektif. Kurikulum 2006 (KTSP) dikembangkan menjadi Kurikulum 2013 dengan dilandasi pemikiran tantangan masa depan yaitu tantangan abad ke 21 yang ditandai dengan abad ilmu pengetahuan, knowledge-based society dan kompetensi masa depan (Puskur Balitbang, 2001). Pendapat di atas dipertegas oleh Nuh (2013) Pemikiran pengembangan Kurikulum 2013 dikembangkan atas dasar taksonomi-taksonomi yang diterima secara luas, kajian KBK 2004, KTSP 2006, dan tantangan abad ke-21 serta penyiapan generasi 2045.

Kurikulum 2013 ini memberi peluang bagi guru untuk melakukan inovasi dan improvisasi disekolah mirip dengan KTSP, berkaitan dengan masalah kurikulum, pembelajaran, manajerial dan lain sebagainya yang tumbuh dari aktivitas, kreativitas, dan profesionalisme yang dimiliki. Guru diharapkan dapat melaku- kan proses pembelajaran yang efektif, dapat mencapai tujuan yang diharapkan, materi yang diajarkan relevan dengan kebutuhan masyarakat, berorientasi pada hasil (output), dan dampak (outcome), serta melakukan penilaian, pengawasan, dan pemantauan secara terus menerus. Untuk itu, aspek kesiapan guru sebelum menerapkan kurikulum 2013 menjadi bahan kajian yang menarik untuk ditelaah secara lebih mendalam, sehingga dalam proses pembelajaran yang merupakan realisasi dari penerapan kurikulum akan berjalan dengan baik.

Setelah kita mengetahui pentingnya peranan kurikulum dalam pembelajaran, maka sudah sewajarnya kita melakukan beberapa terobosan untuk mengetahui implementasi kurikulum baru. Oleh karena itu, berdasarkan uraian latar belakang di atas, maka rumusan masalah dalam penelitian ini adalah sebagai berikut: (1) Bagaimanakah kesiapan guru-guru bahasa Indonesia SMP dalam mempelajari/ memahami kurikulum 2013, menyiapkanperangkat pembelajaran, dan menyiapkan materi pembelajaran? (2) Apakah faktorfaktor pendukung dan penghambat yang terjadi dalam persiapan pembelajaran menggunakan kurikulum 2013?

\section{METODE}

Pendekatan yang digunakan dalam penelitian ini adalah pendekatan survai. Pendekatan survai adalah prosedur penelitian yang menggunakan kajian eksploratoris untuk mengetahui kesiapan guru-guru dalam mengimplentasikan kurikulum 2013. Data-data penelitian diperoleh dari angket yang diisi oleh guru. Data-data yang diperoleh kemudian dianalisis secara deskripsi melalui kategorisasi berdasarkan karakteristik masing-masing.

Subjek penelitian ini adalah guruguru pengajar bahasa Indonesia SMP di Kabupaten Kulonprogo Yogyakarta. Penelitian ini dilakukan pada guru-guru 
SMP yang mengajar bahasa Indonesia berjumlah 23 guru. Subjek penelitian dilakukan dengan cara purposif sampling. Artinya, guru-guru yang menjadi subjek penelitianadalah yang aktif mengikuti MGMP mata pelajaran bahasa Indonesia di Kabupaten Kulonprogo.

Penelitian ini dilaksanakan di sekolahsekolah (SMP) yang berada di Kabupaten Kulonprogo. Populasi penelitian ini adalah guru-guru Bahasa Indonesia SMP yang tersebar pada beberapa sekolah di Kabupaten Kulonprogo. Untuk waktu penelitian, dilakukan pada bulan Juli sampai dengan Desember 2013 pada jam dan hari kerja. Penelitian ini dilaksanakan selama enam bulan.

Instrumen dalam penelitian ini menggunakan angket. Angket sebelum digunakan didiskusikan dan divalidasi oleh ahli sekaligus pembimbing. Angket digunakan setelah dinyatakan valid oleh ahli yaitu Dr. Kastam syamsi, M.Ed. Angket digunakan atau dibagikan ke guru-guru untuk mengetahui kesiapan guru-guru bahasa Indonesia SMP dalam mengimplentasikan Kurikulum 2013.

Pengumpulan data menggunakan angket. Data yang terkumpul melalui angket guru, kemudian dianalisis secara deskriptif. Analisis data melalui kategorisasi/pengelompokan setiap komponen. Data-data dikelompokan dan dideskripsikan untuk menjawab rumusan dalam penelitian ini.

Analisis data dimulai dengan menelaah seluruh unsur-unsur data yang berasal dari angket dan pengamatan. Setelah dibaca, dipelajari dan ditelaah, langkah selanjutnya adalah mengadakan reduksi data. Reduksi data merupakan proses pemilihan, pemusatan, dan penyederhanaan data kasar yang muncul dari hasil di lapangan.

\section{HASIL DAN PEMBAHASAN}

Data yang diperoleh dengan instrumen angket dianalisis dengan teknik statistik deskriptif. Penilaian dilakukan dengan pengklasifikasian interval lima. Pada setiap interval akan menunjukkan kategori, skor, dan persentase. Aspek kategori digunakan untuk mengetahui kesiapan guru secara kualitatif, sedangkan skor dan persentase untuk mengetahui kesiapan guru secara kuantitatif berdasarkan hasil data. Kategori yang digunakan adalah sangat tidak siap, tidak siap, cukup siap, siap dan sangat siap. Untuk penggolongan skor dan persentase dapat dilihat dalam Tabel 1.

Tabel 1. Data Kuantitatif Interval Lima

\begin{tabular}{lcc}
\hline \multicolumn{1}{c}{ Kategori } & Skor & Persentase \\
\hline Sangat Siap & 5 & $81-100 \%$ \\
Siap & 4 & $61-80 \%$ \\
Cukup Siap & 3 & $41-60 \%$ \\
Tidak Siap & 2 & $21-40 \%$ \\
Sangat Kurang & 1 & $0-20 \%$ \\
\hline
\end{tabular}

Profil kategori digunakan peneliti untuk membahas hasil penelitian secara kualitatif. Selanjutnya, penjelasan atau profil dari masing-masing kategori tersebut di atas adalah sebagai berikut. Pertama, kategori sangat tidak siap artinya guru tidak mengetahui dan memahami isi kurikulum, tidak membuat rencana program pembelajaran (RPP), tidak menyiapkan materi dan strategi pembelajaran serta tidak mengevaluasi pembelajaran sesuai dengan kurikulum 2013. Kedua, kategori tidak siap artinya guru tidak memahami isi kurikulum (membaca kurikulum 2013), tidak membuat rencana pembelajaran (RPP), tidak menyiapkan materi dan strategi serta tidak mengevaluasi pembelajaran sesuai dengan kurikulum 2013. Ketiga, kategori cukup siap artinya guru sedikit memahami isi kurikulum (tidak menyeluruh), guru menyiapkan rencana pembelajaran (RPP), materi, strategi dan mengevaluasi pembelajaran tetapi hanya tuntutan dari sekolah. Semua perangkat pembelajaran (perencanaan, pelaksanaan 
dan evaluasi) yang dimiliki guru hasil fotokopi (copy paste) dari teman guru di MGMP. Keempat, kategori, siap artinya guru memahami isi kurikulum tetapi tidak sampai kepraktiknya atau penerapannya. Guru menyiapkan rencana pembelajaran (RPP), materi dan strategi serta mengevaluasi pembelajaran tetapi hanya mengikuti tuntutan dari sekolah/Instansi. Guru sudah menyusun perangkat pembelajaran dari perencanaan, pelaksanaan dan evaluasi secara mandiri ataupun kelompok di MGMP, tetapi belum menerapkannya di sekolah.Kelima, kategori, sangat siap artinya guru memahami isi kurikulum (menyeluruh ke buku guru dan sampai praktik ke siswa), guru menyiapkan rencana pembelajaran (RPP), materi, strategi, dan mengevaluasi pembelajaran sesuai dengan kurikulum 2013. Guru sudah menyusun perangkat pembelajaran dari perencanaan, pelaksanaan dan evaluasi secara mandiri ataupun kelompok di MGMP dan mampu menerapkannya di sekolah.

Pembahasan hasil penelitian akan dilakukan perkomponen dengan berdasarkan hasil angket yang diisi oleh guru. Adapun komponen pembahasan hasil penelitian ini yaitu; pertama, kesiapan guru dalam mengimplementasikan kurikulum 2013 yang meliputi (1) pemahaman guru pada aspek isi kurikulum, (2) perencanaan pembelajaran, (3) pelaksanaan pembela- jaran, dan (4) pemahaman guru terhadap evaluasi atau ketuntasan belajar. Kedua, faktor-faktor pendukungdan penghambat yang terjadi dalam persiapan pembelajaran menggunakan kurikulum 2013.

\section{Kesiapan Guru Mengimplementasikan Kurikulum 2013}

Berdasarkan hasil penelitian, secara umum guru siap mengimplementasikan kurikulum 2013 di sekolah masing-masing. Kesiapan guru akan dibahas berdasarkan profil kategori yang telah dijelaskan secara kuallitatif. Untuk melihat kesiapan guru dalam mengimplementasikan kurikulum 2013 akan dibahas sesuai dengan komponen-komponen yang telah dikelompokan, yaitu (a) pemahaman terhadap isi kurikulum, (b) kesiapan dalam perencanaan pembelajaran, dan (c) kesiapan dalam pelaksanaan pembelajaran.

\section{Pemahaman Guru pada Aspek Isi Kuri- kulum}

Secara umum dinyatakan bahwa tingkat kesiapan guru-guru Bahasa Indonesia SMP di Kulon Progo dalam mengimplementasikan kurikulum 2013 di sekolah pada aspek isi sudah baik. Persentase aspek isi yang diperoleh dari penilaian semua guru adalah $68,91 \%$, yaitu termasuk dalam kategori siap berdasarkan pengklasifikasian interval lima. Hal itu menunjukkan bahwa secara umum, guru-guru

Tabel 2. Hasil Penilaian Aspek Isi

\begin{tabular}{llcc}
\hline No. & \multicolumn{1}{c}{ Pernyataan } & $\begin{array}{c}\text { Jumlah } \\
\text { Tiap Pernyataan }\end{array}$ & $\begin{array}{c}\text { Skor } \\
\text { Maks }\end{array}$ \\
\hline 1. & $\begin{array}{l}\text { Muatan Kurikulum 2013 sesuai dengan kebutuhan siswa } \\
\text { dalam pembelajaran Bahasa Indonesia di sekolah. }\end{array}$ & 84 & 115 \\
2. $\begin{array}{l}\text { Kompetensi Inti dan Kompetensi Dasar relevan terhadap } \\
\text { kebutuhan siswa. }\end{array}$ & 83 & 115 \\
3. $\begin{array}{l}\text { Kompetensi Dasar mudah dipahami dan dimengerti oleh } \\
\text { guru. }\end{array}$ & 74 & 115 \\
$\begin{array}{l}\text { Isi (substansi) kurikulum 2013 mudah dipahami oleh } \\
\text { guru untuk dasar penyusunan RPP. }\end{array}$ & $\begin{array}{r}\text { Jumlah } \\
\text { Persentase }\end{array}$ & $\begin{array}{c}717 \\
68,91 \%\end{array}$ & 115 \\
\hline
\end{tabular}

LITERA, Volume 13, Nomor 2, Oktober 2014 
Bahasa Indonesia SMP di Kulonprogo telah siap untuk mengimplemetasikan kurikulum 2013 dalam proses belajar mengajar di kelas. Deskripsi selengkapnya tersaji dalam Tabel 2.

Meskipun demikian, ada beberapa hal yang perlu diperhatikan dari aspek isi karena beberapa guru berpendapat bahwa (1) kompetensi dasar kurang bisa dipahami dan dimengerti guru dan (2) Isi (substansi) kurikulum 2013 kurang bisa dipahami oleh guru untuk dasar penyusunan RPP. Dengan demikian, kedua hal itulah yang diharapkan dapat menjadi perhatian dan bahan pertimbangan pemerintah terkait dengan pelaksanaan kurikulum 2013.

Tingkat kesiapan guru dalam mengimplementasikan isi kurikulum 2013 tergolong siap. Kategori siap artinya guru memahami isi kurikulum tetapi tidak sampai kepraktiknya atau penerapannya. Guru hanya membaca draf kurikulum yang diberikan peneliti, tetapi belum membaca dan mempelajari buku guru dan buku siswa untuk dituangkan dalam penyusunan RPP dan pelaksanaannya. Oleh karena itu, perangkat pembelajaran yang dimiliki oleh guru hanya sebatas fotokopi dari teman di MGMP. Selain itu, yang masih perlu diperhatikan adalah tingkat pemahaman guru terhadap muatan isi dalam kurikulum. Guru belum dapat memahami kompetensi dasar (KD 1 sampai dengan KD 4) dan pengembangan indikator dengan baik. Mereka ketika menyusun Rencana Program Pembelajaran (RPP) belum menunjukan pengembangan dari isi kurikulum 2013. Ketika menyusun rencana pembelajaran, guru masih berpatokan pada buku pegangan dan RPP yang lama.Strategi yang digunakan pun belum kreatif, kompetitif dan mengaktifkan siswa.

Guru belum memahami isi kurikulum secara utuh. Pertama, Standar Kompetensi Lulusan (SKL) belum diturunkan dari kebutuhan siswa. Artinya, kebutuhan siswa di masa yang akan datang belum ditentukan terlebih dahulu, kemudian SKL-nya dirumuskan (Darmaningtyas, 2013). Tujuannya adalah agar nantinya siswa dapat menghadapi tantangan global. Oleh karena itu, kompetensi siswa di masa yang akan datang adalah kemampuan berkomunikasi, berpikir jernih, kritis, bermoral, bertanggung jawab dan cerdas. Dengan mengacu pada SKL itulah diturunkan dari Standar Isi kurikulum (mata pelajaran).

Pada Kurukulum 2013, Standar Isi diturunkan dari SKL melalui Kompetensi Inti (KI) ke mata pelajaran (Bahasa Indonesia). Kompetensi inti mencakup sikap religious (moral), sosial, pengetahuan, dan aplikasi pengetahuan. Dalam pembelajaran bahasa Indonesia pun terkandung Kompetensi Inti. Pada Kurikulum KBK 2004 dan KTSP 2006 Standar Isi dirumuskan berdasarkan tujuan Mata Pelajaran yang dirinci menjadi Standar Kompetensi (SK) dan Kompetensi Dasar (KD). Hal tersebut yang membedakan antara kurikulum KTSP 2006 dengan kurikulum 2013.

\section{Kesiapan Guru dalam Perencanaan Pem- belajaran}

Pada Tabel 3 terlihat bahwa persentase penilaian seluruh guru pada aspek perencanaan adalah $68,69 \%$ atau berada dalam kategori siap. Hal itu menunjukkan bahwa dari segi perencanaan, secara umum guru-guru Bahasa Indonesia SMP di Kulon Progo telah siap untuk mengimplementasikan kurikulum 2013 dalam PBM di kelas. Namun, seperti halnya dengan aspek isi, pada aspek perencanaan ini pun terdapat beberapa hal yang perlu dikaji lebih lanjut, yaitu: 1) penyusunan RPP dan 2) proporsi materi berbahasa dan bersastra yang dimuat dalam kurikulum 2013. Berdasarkan angket yang diisi oleh guru dapat diketahui bila terdapat beberapa guru berpendapat bahwa penyusunan RPP kurikulum 2013 tidak 
Tabel 3. Hasil Penilaian Aspek Perencanaan

\begin{tabular}{|c|c|c|c|}
\hline No. & Pernyataan & $\begin{array}{c}\text { Jumlah } \\
\text { Tiap-tiap } \\
\text { Pernyataan }\end{array}$ & $\begin{array}{c}\text { Skor } \\
\text { Maksimal }\end{array}$ \\
\hline 1. & $\begin{array}{l}\text { Rencana Program Pembelajaran (RPP) mudah disusun } \\
\text { berdasarkan isi kurikulum } 2013 .\end{array}$ & 78 & 115 \\
\hline 2. & Tujuan pembelajaran tercermin dalam Kurikulum 2013. & 84 & 115 \\
\hline \multirow[t]{2}{*}{3.} & $\begin{array}{l}\text { Materi berbahasa dan bersastra secara proporsional termuat } \\
\text { dalam kurikulum. }\end{array}$ & 75 & 115 \\
\hline & $\begin{array}{r}\text { Jumlah } \\
\text { Persentase }\end{array}$ & $\begin{array}{c}237 \\
68,69 \% \\
\end{array}$ & 345 \\
\hline
\end{tabular}

mudah dilaksanakan. Kesulitan itu terutama ketika guru mengaitkan kompetensi dasar dengan strategi pembelajaran yang tepat. Hal itu dikarenakan, panduan atau model RPP dari pemerintah hanya menggunakan strategi scientific. Oleh karena itu, guru dituntut untuk dapat menyisipkan atau menggunakan strategi atau metode pembelajaran baru yang lebih tepat dan kreatif.

Kesiapan guru dalam perencanaan pembelajaran masuk dalam kategori siap. Artinya, guru menyiapkan rencana pembelajaran (RPP), materi dan strategi pembelajaran tetapi hanya mengikuti tuntutan dari sekolah/Instansi. RPP yang dimiliki guru adalah perbaikan dari kurikulum sebelumnya dan atau RPP hasil fotokopi (copypaste) dari teman di MGMP. Materi dan strategi yang digunakan pun masih konvensional dan belum menyesuaikan kurikulum 2013.

Berdasarkan hasil data penelitian (angket) diperoleh bahwa beberapa guru berpendapat bahwa penyusunan RPP kurikulum 2013 tidak mudah dilaksanakan. Guru sulit untuk mengatur waktu agar materi kebahasaan dan sastra dapat diajarkan semuanya. Selain itu, guru masih kurang menguasai berbagai jenis strategi dan metode pembelajaran yang kan diterapkan dalam setiap pembelajaran.

Asumsi terkait dengan kesulitan penyusunan RPP, yaitu bahwa kurikulum
2013 menuntut kerincian dan kreativitas guru dalam menyusun RPP sebagai salah satu perangkat perencanaan pembelajaran sehingga perlu adanya pembiasaan bagi guru agar para guru tidak lagi merasa kesulitan untuk menyusun RPP. Guru dituntut kemandirianya supaya mampu menjabarkan Kompetensi Inti untuk dirumuskan dalam RPP agar pembelajaran menjadi lebih bermakna.

Selanjutnya, perlu dikaji ulang terkait dengan proporsi materi berbahasa dan bersastra dalam kurikulum 2013 agar lebih proporsional sehingga kemampuan yang diterima siswa pun seimbang antara kemampuan berbahasa dan bersastra. Melihat materi, porsi dan kekhususan sastra, seorang guru bahasa dan sastra dituntut mempunyai kompetensi, keprofesional, dan pendidikan yang mendukung pada pebelajaran sastra selain kemampuan umum lainnya. Setelah guru mempunyai kriteria seperti di atas tentunya guru akan mudah memberikan pembelajaran sastra sesuai dengan tujuan pembelajaran dalam Kurikulum 2013. Meskipun materi sastra dibandingkan dengan bahasa dalam kurikulum 2013 tidak proporsional, tetapi guru dituntut untuk kreatif menyisipkan materi sastra dalam kegiatan keterampilan berbahasa.

\section{Kesiapan Guru dalam Melaksanakan Pem- belajaran}

Secara umum, dilihat dari aspek pelaksanaan para guru SMP di Kabupaten 
Tabel 4. Hasil Penilaian Aspek Pelaksanaan

\begin{tabular}{|c|c|c|c|}
\hline No. & Pernyataan & Jumlah & $\begin{array}{c}\text { Skor } \\
\text { Maksimal }\end{array}$ \\
\hline 1. & $\begin{array}{l}\text { Buku ajar dari pemerintah sudah mencerminkan materi dalam } \\
\text { Kurikulum } 2013 .\end{array}$ & 78 & 115 \\
\hline 2. & $\begin{array}{l}\text { Perlu diberi materi pengayaan selain buku ajar yang diberikan } \\
\text { oleh pemerintah. }\end{array}$ & 97 & 115 \\
\hline 3. & $\begin{array}{l}\text { Keterampilan membaca, menulis, berbicara, dan menyimak } \\
\text { secara proporsional muncul dalam Kurikulum } 2013 .\end{array}$ & 80 & 115 \\
\hline 4. & Pendekatan, metode, dan strategi dapat dipahami oleh guru. & 83 & 115 \\
\hline 5. & Strategi pembelajaran mudah diterapkan dalam pembelajaran. & 77 & 115 \\
\hline 6. & Media pembelajaran dapat dipilih dan dipahami oleh guru. & 80 & 115 \\
\hline \multirow[t]{2}{*}{7} & $\begin{array}{l}\text { Pembelajaran sudah berpusat pada keaktifan siswa (student } \\
\text { active learning). }\end{array}$ & 90 & 115 \\
\hline & $\begin{array}{r}\text { Jumlah } \\
\text { Persentase }\end{array}$ & $\begin{array}{c}585 \\
72,67 \% \\
\end{array}$ & 805 \\
\hline
\end{tabular}

Kulon Progo telah siap mengimplementasikan kurikulum 2013 dalam PBM di kelas sesuai dengan hasil penilaian para guru seperti yang terlihat pada Tabel 4 . Pada Tabel 4, persentase aspek pelaksaan mencapai $72,67 \%$ atau berada dalam kategori siap.

Kesiapan guru dalam melaksanakan Kurikulum 2013 dalam kategori siap. Artinya, guru sudah menyiapkan rencana pembelajaran (RPP), materi dan strategi serta mengevaluasi pembelajaran tetapi hanya mengikuti tuntutan dari sekolah/ pemerintah. Dalam pelaksanaannya, guru masih menggunakan strategi lama dan masih berpatokan pada RPP dan materi yang diberikan oleh intansi/pemerintah. Guru belum membuat dan mengembangkan sendiri RPP, materi dan strategi berdasarkan karakteristik sekolah masing-masing.

Berdasarkan hasil data penelitian (angket) terdapat beberapa hal yang perlu diperhatikan terkait dengan pelaksanaan kurikulum 2013. Hasil penilaian guru dari angket yang diberikan, yaitu: (1) perlu diberi materi pengayaan selain buku ajar yang diberikan oleh pemerintah, (2) keterampilan membaca, menulis, berbicara, dan menyimak kurang proporsional da- lam Kurikulum 2013, dan (3) beberapa guru berpendapat bahwa metode dan strategi pembelajaran tidak mudah diterapkan dalam pembelajaran.

Menurut penyataan guru, materi pengayaan sangat dibutuhkan dalam mengimplementasikan kurikulum 2013. Selain itu, guru-guru bahasa Indonesia SMP di Kulonprogo masih menggunakan buku pegangan dari pemerintah. Mereka belum kreatif mencari materi-materi untuk menunjang proses pembelajaran di kelas. Analisis kebutuhan dan kesesuaian materi dengan siswa juga belum diperhatikan. Oleh karena itu, guru-guru bahasa Indonesia di Kulon Progo membutuhan perubahan pola berpikir baru (mindset) untuk meramu sendiri materi pembelajaran yang kreatif, inovatif, dan mencerdaskan. Sebagian besar guru masih sangat patuh mengikuti petunjuk (buku ajar) yang diberikan oleh Dinas Pendidikan tanpa ada upaya kreatif dalam menyiapkan materi dari sumber lain.

Berikutnya, menurut guru keterampilan berbahasa yang termuat dalan kurikulum 2013 tidak proporsional. Ternyata, guru belum dapat memahami bahwa Kurikulum 2013 lebih menekankan pada kemampuan dan keterampilan berbasis 
teks (lisan dan tulis).Sedangkan kurikulum KTSP lebih menekankan pada empat keterampilan berbahasa (berbicara, membaca, menulis dan menyimak). Hal itulah yang membedakan kompetansi dasar antara kurikulum 2006 dengan Kurikulum 2013. Pada kurikulum 2013, keterampilan yang porsinya paling banyak adalah keterampilan menulis dan membaca. Menurut guru, keterampilan menyimak dan berbicara porsinya lebih sedikit. Oleh karena itu, guru merasakan keterampilan menyimak dan berbicara kurang diperhatikan dan kurang mendalam. Oleh karena itu, guru harus mampu membagi sendiri proporsi empat keterampilan berbahasa tersebut dalam Proses Belajar Mengajar (PBM). Akan tetapi, hasil penyataan guru tersebut penting untuk ditindaklanjuti penyusun dan pengembang Kurikulum 2013 agar menjadi lebih baik.

Selain kurangnya materi pengayaan dan kurang proporsionalnya keterampilan berbahasa, pelaksanaan pembelajaran bahasa Indonesia perlu mengedepankan pengalaman personal melalui proses mengamati, bertanya, bernalar, mencoba (observation based learning), dan mempublikasi untuk meningkatkan kreativitas peserta didik. Dalam proses pembelajaran, siswa harus dibiasakan untuk bekerja secara bersama-sama (collaborative learning). Guru-guru SMP di Kulon Progo, harus selalu berorientasi pada pembelajaran kolaboratif dan bermakna. Hal tersebut dikarenakan pembelajaran bahasa Indonesia berdasarkan Kurikulum 2013 bertujuan untuk menciptakan pembelajaran yang kritis, kreatif, kolaboratif, dan bermakna. Akan tetapi, dalam pembelajaran bahasa Indonesia, guru-guru SMP di Kulon Progo belum melakukan hal tersebut secara utuh. Hal itu dikarenakan minimnya guru menguasai strategistrategi pembelajaran yang tepat untuk setiap pebelajaran.

Guru-guru SMP di Kulon Progo dalam proses pembelajaran mengatakan belum menggunakan metode dan strategi yang baru. Guru-guru masih menggunakan metode dan strategi lama sesuai dengan kurikulum KTSP 2006. Artinya, guru-guru SMP di Kulon Progo belum menguasai strategi-strategi baru yang sesuai dengan materi pembelajaran untuk mengimplementasikan kurikulum 2013. Metode dan strategi yang digunakan guru yaitu, penugasan, tanya jawab, diskusi, brainstorming, ceramah, dan membaca estetis. Guru belum menemukan strategi-strategi baru yang membangun kemampuan siswa untuk mampu berkomunikasi, kritis, kreatif dan menguasai pengetahuan.

\section{Pemahaman Guru terhadap Ketuntasan Belajar dan Evaluasi}

Berdasarkan hasil analisis angket yang telah diberikan, dapat diketahui bahwa aspek evaluasi dalam kurikulum 2013 berada dalam kategori siap, yakni mencapai 67,83\% sesuai dengan Tabel 5 di bawah. Meskipun demikian, terdapat beberapa guru yang berpendapat bahwa evaluasi dan ketuntasan belajar tidak mudah di-

Tabel 5. Hasil Penilaian Aspek Evaluasi

\begin{tabular}{llcc}
\hline No. & \multicolumn{1}{c}{ Pernyataan } & $\begin{array}{c}\text { Jumlah Tiap-tiap } \\
\text { Pernyataan }\end{array}$ & $\begin{array}{c}\text { Skor } \\
\text { Maksimal }\end{array}$ \\
\hline 1. & $\begin{array}{l}\text { Evaluasi dan ketuntasan belajar dapat dipahami oleh } \\
\text { guru }\end{array}$ & 78 & 115 \\
2. & $\begin{array}{l}\text { Ketuntasan belajar meliputi aspek sikap, sosial, } \\
\text { pengetahuan, dan keterampilan }\end{array}$ & 70 & \\
& & Jumlah & 74 \\
& Persentase & $66,83 \%$ & 115 \\
\hline
\end{tabular}


pahami oleh guru sesuai dengan hasil analisis angket, sehingga perlu dikaji lebih lanjut atau dilakukan sosialisasi lanjutan kepada para guru bahasa Indonesia SMP di Kulon Progo. Evaluasi yang dilakukan oleh guru seharusnya berbasis otentik. Artinya, guru harus melihat kemampuan siswa seacara langsung berdasarkan kemampuannya selama proses pembelajaran. Selain itu, aspek-aspek kompetensi yang harus dinilai saat dan setelah pembelajaran adalah sikap (afektive), sosial, pengetahuan dan kemampuan/keterampilan. Keempat aspek itulah yang menjadi target tercapainya pembelajaran berdasarkan Kurikulum 2013.

Berdasarkan hasil data penelitian beberapa guru berpendapat bahwa evaluasi dan ketuntasan belajar tidak mudah dipahami oleh guru. Hasil data menunjukkan, guru masuk dalam kategori siap untuk melakukan evaluasi pembelajaran. Akan tetapi, kesiapan itu hanya sebatas melakukan evaluasi berdasarkan panduan yang sudah disediakan pemerintah. Itupun tidak semuanya dapat dipahami oleh guru. Guru belum siap menyusun sendiri evaluasi pembelajaran untuk diterapkan di sekolahnya masing-masing.

Proses penilaian dengan kurikulum 2013 seharusnya menekankan pada proses dan hasil, sehingga diperlukan penilaian berbasis portofolio. Evaluasi tertulis yang dilakukan guru selain berbentuk soal uraian, essai, dan objektif juga memakai penilaian portofolio, yaitu penilaian yang diperoleh dari proses belajar mengajar yang berupa unjuk kerja siswa. Untuk penilaian bentuk portofolio ini termasuk dalam kategori penilaian proses.

Hasil data menunjukan, semua guru melakukan evaluasi secara lisan dan tertulis. Evaluasi lisan dilakukan saat proses pembelajaran berlangsung, sedangkan evaluasi tertulis dilakukan saat pembelajaran dan sesudah pembelajaran. Evaluasi lisan dilakukan guru untuk mengetahui tingkat kompetensi siswa tentang pemahaman materi yang telah disampaikan. Evaluasi lisan selain untuk mengetahui tingkat penguasaan teori siswa juga untuk mengetahui tingkat penguasaan pengetahuan siswa.

Guru-guru SMP di Kulon Progo belum melihat tingkat keberhasilan siswa dinilai dari tingkat Kompetensi Dasar dan Kompetensi Inti yang dikuasai dalam kurikulum 2013. Artinya, siswa seharusnya mengetahui tingkat penguasaan dan pemahaman pada materi tertentu, sehingga siswa akan mengetahui kemampuannya sendiri. Penilaian ini berkaitan dengan sistem porto folio yang telah dilaksanakan guru bahwa model porto folio pada hakekatnya menilai siswa dari belum tahu menjadi tahu, sehingga penilaian proses akan lebih dominan daripada penilaian hasil.

Guru-guru SMP di Kulon Progo tidak semua melakukan evaluasi sikap atau afektif, sosial, kognitif dan keterampilan dalam pembelajaran bahasa. Menurut Ruwanto (2013) evaluasi afektif dilakuan untuk mengetahui sikap dan perilaku siswa saat pembelajaran berlangsung. Evaluasi sosial untuk mengetahui tingkat soaial dan kerjasama siswa dalam pembelajaran. Evaluasi kognitif dilakukan untuk mengukur kemampuan siswa saat pembelajaran berbahasa. Evaluasi kognitif dilakukan oleh guru untuk mengetahui tingkat pemahan teori dan pengetahuan bahasa yang telah dikuasai siswa setelah pembelajaran. Evaluasi kemampuan atau keterampilan untuk mengetahui keterampilan siswa dalam mempraktikan kompetensi yang menjadai tujuan pembelajaran. Oleh karena guru belum melakukan evaluasi pada keempat aspek tersebut, pemerintah perlu mengkaji lebih lanjut atau melakukan sosialisasi lanjutan mengenai evaluasi pembelajaran dalam Kurikulum 2013 kepada para guru Bahasa Indonesia SMP di Kulon Progo. 
Faktor-faktor Penghambat dan Pendukung Implementasi Kurikulum 2013

Diterapkannya Kurikulum 2013, tentunya akan mengalami banyak perubahan pada sistem pembelajarannya. Adanya perubahan sistem pembelajaran ini, guru akan mengalami kendala dalam pelaksanaan. Faktor-faktor penghambat dan pendukung yang perlu dibahas untuk menunjang proses implementasi Kurikulum 2013 adalah sebagai berikut.

Faktor-faktor penghambat guru bahasa Indonesia dalam mengimplementasikan kurikulun 2013 adalah terbatasnya buku-buku baru, kurangnya materi pembelajaran sastra, dan terbatasnya waktu belajar kelompok. Lebih jelasnya faktorfaktor tersebut diuraikan sebagai berikut.

Pertama, terbatasnya buku-buku baru. Di dalam Kurikulum 2013, guru untuk menentukan bahan pembelajaran hendaknya sesuai dengan keadaan siswa dan sesuai dengan perkembangan di masyarakat. Akan tetapi, guru-guru SMP di Kulonprogo merasa kesulitan untuk mencari bahan dari luar sekolah. Mereka menyatakan tidak sulit mencari buku-buku baru berdasarkan muatan Kurikulum 2013. Guru-guru hanya mempelajari buku dari pemerintah yang jumlahnya masih sangat terbatas dan kualitasnya juga belumbaik. Hal itu dibuktikan dengan beberapa temuan guru tentang kekurangan dan kelemahan buku (bahasa, diksi, dan gambar yang tidak sesuai dengan siswa) dari pemerintah.

Karena terbatasnya buku-buku baru inilah yang menyebabkan persiapan pelaksanaan pembelajaran berdasarkan Kurikulum 2013 menjadi tidak interaktif. Guru kurang termotivasi, sehingga masih memilih menggunakan buku lama (Kurikulum KTSP 2006).

Kedua, kurangnya materi pembelajaran Sastra. Di dalam Kurikulum 2013, materi pembelajaran sastra dengan nonsastra berdiri sendiri. Kompetensi Dasar pembelajaran sastra di SMP meliputi cerita pendek (kelas VII), cerita moral/ fabel, cerita prosedur, dan cerita biografi (kelas VIII), sedangkan di kelas IX tidak ada materi sastra. Akan tetapi, materi sastra dalam buku guru dan buku siswa sebenarnya sudah muncul secara proporsional. Meskipun demikian, yang menjadi patokan guru adalah kurikulum bukan buku guru atau buku siswa, sehingga guru lebih berpatokan pada isi/muatan kurikulum daripada buku.

Selain itu, guru kesulitan untuk mengembangkan indikator dalam pembelajaran sastra, karena keterbatasan waktu yang tersedia. Materi sastra hanya terkait dengan teks cerita, sedangkan teks sastra yang lain tidak muncul dalam draf Kurikulum 2013. Akan tetapi, kalau dicermati materi sastra seperti puisi, cerpen, dan novel muncul dalam buku guru dan buku siswa dari pemerintah. Hal tersebutlah yang menjadikan guru, tidak sepenuhnya melaksanakan pembelajaran sastra dengan maksimal. Guru hanya memilih materi sastra yang dikuasai, karena menganggap materi sastra (puisi dan novel) bukan hal wajib yang perlu diajarkan pada siswa.

Selain itu, adanya pembatasan materi sastra, membuat guru tidak berani menyisipkan materi sastra ke materi bahasa. Hal ini berpengaruh terhadap guru untuk mengembangkan pembelajaran sastra di kelas. Guru kurang bebas menentukan materi dalam pembelajaran karena keterbatasan waktu yang tersedia dalam silabus pembelajaran berdasarkan Kurikulum 2013.

Ketiga, keterbatasan Waktu untuk Belajar Kelompok. Karena sistem pembelajaran memakai metode kelompok tentunya membutuhkan waktu yang lama. Hal ini disebabkan untuk mencapai ketuntasan materi yang ingin disampaikan pada siswa. Selain itu, ketika siswa ingin berinteraksi antarkelompok dan guru, maka akan banyak pendapat yang muncul di 
kelas. Karena keterbatasan waktu belajar inilah yang menyebabkan materi tidak sampai pada ketuntasan untuk tercapainya kompetensi siswa.

Keterbatasan waktu untuk belajar kelompok (colaborative learning) inilah yang menyebabkan tujuan pembelajaran tidak tercapai. Misalnya pada saat membahas mengenai teks prosedur, maka dalam setiap kelompok atau setiap siswa mempunyai pendapat yang berbeda-beda. Pendapat yang berbeda-beda inilah yang menyebabkan penggunaan waktu yang terlalu banyak.

Selanjutnya, faktor-faktor pendukung guru bahasa Indonesia dalam mengimplemetasikan kurikulun 2013 adalah memperbanyak sosialisasi kurikulum, kreativitas guru mengajar, dan memperbanyak buku-buku pendukung.

Menurut wawancara dengan guru, diperoleh data bahwa sebagian besar guru (75\%) yang menjadi responden penelitian ini belum pernah mengikuti sosialisasi (pelatihan) implementasi Kurikulum 2013. Mereka justru mengetahui dan membaca isi Kurikulum 2013 dari peneliti ketika mengisi angket. Guru-guru SMP Kulon Progo yang sudah pernah mengikuti pelatihan adalah guru yang mengajar di sekolah yang ditunjuk Dinas Pendidikan untuk menerapkan Kurikulum 2013. Guru-guru tersebut berasal dari SMP N 1 Wates, SMP N 1 Galur, SMP N Lendah, SMP N 1 Samigaluh, dan SMP Pangudi Luhur Kalibawang.

Pemerintah sudah seharusnya melakukan sosialisasi/pelatihan implementasi Kurikulum 2013 dengan lebih intensif. Kementerian Pendidikan dan Dinas Pendidikan harus berani merekrut para guru yang progresif, guru-guru dari sekolah alternatif, aktivis pendidikan, guru-guru dari sekolah internasional untuk direkrut menjadi instruktur. Guru-guru inilah yang nantinya menjadi ujung tombak di daerahnya masing-masing untuk mensosialisasikan kurikulum 2013.
Dalam Kurikulum 2013 pembelajaran sastra dan nonsastra berdiri sendiri. Hal ini meyebabkan guru mengalami hambatan dalam melakukan pengembangan indikator pengajaran sastra. Artinya, untuk ke depan materi sastra tidak bisa berkembang secara luas. Langkah yang memungkinkan dilakukan guru untuk mengatasi hal ini yaitu keberanian dan kekreatifan guru menyisipkan materi sastra ke materi nonsatra. Dengan menyisipkan beberapa materi sastra ke bahasa nantinya guru akan bebas mengembangkan materi sastra dengan materi kebahasaan secara berkaitan. Hal ini juga untuk memacu siswa agar tidak bosan menerima pembelajaran bahasa secara terus menerus. Untuk itu terkadang perlu adanya kolaburasi antara materi sastra dengan bahasa yang mempunyai keterkaitan.

Kementerian Pendidikan dan Dinas Pendidikan daerah harus lebih serius menambah buku-buku teks yang berkualitas ke sekolah. Menurut pendapat guru, buku teks berdasarkan Kurikulum 2013 di sekolah-sekolah masih kurang terutama di daerah-daerah. Guru-guru yang sudah menerima buku dari pemerintah hanya sekolah-sekolah yang ditunjuk pemerintah untuk menerapkan kurikulum 2013, sedangkan sekolah yang lain belum menerima buku baru tersebut. Beberapa guru sudah mempunyai buku guru dan buku siswa (versi pemerintah) berupa soft file dari seminar dan pelatihan yang diikuti. Akan tetapi, guru belum membaca dan memahami isi buku yang diterimanya karena bentuknya soft file. Harapannya, ketika guru sudah menerapkan kurikulum 2013, sebaiknya guru dan siswa sudah mempunyai buku teks yang dicetak dan sesuai dengan kebutuhan siswa untuk masa depan.

Buku teks merupakan salah satu komponen penting dalam proses pembelajaran di sekolah. Di samping mendukung guru dalam pembelajaran, buku teks juga merupakan sumber pengetahuan bagi 
siswa. Oleh karena itu penulisan buku teks harus teliti, serta diupayakan tidak mengandung kesalahan, baik kesalahan konsep maupun isi. Penulisan buku teks harus memperhatikan aspek materi, penyajian dan bahasa. Sudah selayaknya, buku teks yang diberikan pada siswa benar-benar berkualitas dan terhindar dari kesalahan-kesalahan, sehingga tidak menciderai dunia pendidikan kita.

\section{SIMPULAN}

Sebagai penutup uraian ini dapat disimpulkan beberapa hal sebagai berikut. Pertama, dengan memperhatikan karakteristik kurikulum 2013, guru-guru bahasa Indonesia SMP di Kulonprogo tergolong siap mengimplementasikan kurikulum 2013 di sekolah masing-masing. Kesiapan guru dalam mengimplementasikan Kurikulum 2013 dapat dilihat dari aspek pemahaman isi, perencanaan pembelajaran, pelaksanaan pembelajaran, dan ketuntasan belajar. Kategori, siap artinya guru memahami isi kurikulum tetapi tidak sampai kepraktiknya atau penerapannya. Guru menyiapkan rencana pembelajaran (RPP), materi dan strategi serta mengevaluasi pembelajaran tetapi hanya mengikuti tuntutan dari sekolah/pemerintah. Guru belum membuat dan mengembangkan sendiri RPP dan instrumen evaluasi berdasarkan Kurikulum 2013. Akan tetapi, guru hanya mengikuti dan mencontoh RPP atau instrument evaluasi yang sudah ada dari pemerintah.

Kedua, guru-guru Bahasa Indonesia SMP di Kulon Progo meskipun tergolong siap tetapi belum dapat memahami Standar Kompetensi Lulusan (SKL) untuk diturunkan pada kebutuhan siswa. Selain itu, pemahaman Kompetensi Dasar dan Kompetensi Inti belum baik, sehingga ketika menyusun RPP guru masih berpatokan pada buku pegangan dan RPP yang lama.

Ketiga, penguasaan guru terhadap strategi dan metode pembelajaran masih kurang. Mereka menggunakan strategi lama (ceramah, diskusi, dan penugasan) ketika mengajar menggunakan Kurikulum 2013. Guru hendaknya mau mengubah strategi pembelajaran lama dan bukan hanya sekadar skenario di atas kertas rencana pembelajaran.

Keempat, faktor-faktor penghambat kesiapan guru dalam mengimplementasikan Kurikulum 2013 seperti kurangnya pelatihan/sosialisasi kurikulum, kurangnya buku ajar dan porsi materi yang tidak sama harus segera diatasi. Pemerintah, guru, dan praktisi pendidikan secara bersama-sama harus mampu memperbaiki dan mengubah paradigma lama untuk segera menyiapkan diri melaksanakan Kurikulum 2013 dengan lebih kritis.

Gambaran tantangan guru bahasa Indonesia dalam mempersiapkan pelaksanaan Kurikulum 2013 yang disampaikan di atas merupakan bahan yang masih dapat didiskusikan. Karena kurikulum 2013 saat ini masih dalam masa rintisan. Kesiapan Guru dalam pelaksanaan kurikulum 2013, perlu selau ditingkatkan. Tuntutan perubahan kurikulum 2013 menjadi tantangan bagi guru untuk selalu meningkatkan kompetensinya sebagai tenaga profesional.

\section{UCAPAN TERIMA KASIH}

Artikel ini diangkat dari laporan hasil penelitian yang dibiayai oleh dana Anggaran DIPA UNY tahun 2013 alokasi FBS. Oleh karena itu, ucapan terima kasih disampaikan kepada BPP penelitian FBS UNY yang telah mendanai dan menyelenggarakan seminar hasil penelitian. Selanjutnya, ucapan terima kasih disampaikan kepada reviewer, Dr. Kastam Syamsi, M.Ed. yang telah membaca, mengoreksi, dan memberi masukan terhadap laporan dan artikel penelitian ini.

\section{DAFTAR PUSTAKA}

Darmaningtyas. 2013. Mendesain Pelatihan Guru (Opini). Jakarta: Tempo Edisi 26 Juli 2013. 
Depdiknas. 2003. “Kurikulum 2004 Mata Pelajaran Bahasa Indonesia Sekolah Menengah Atas". Jakarta: Depdiknas.

Depdiknas. 2003. "Pedoman Khusus Pengembangan Silabus penilaian Mata Pelajaran Bahasa dan Sastra Indonesia". Jakarta: Depdiknas.

Kemendikbud. 2013. Kompetensi Dasar (Kurikulum Sekolah Menengah Pertama 2013). Jakarta: Kemendikbud.

Kemendikbud. 2013. Kompetensi Dasar (Sekolah Menengah Atas). Jakarta: Kemendikbud.
Mulyasa. 2003. Kurikulum Berbasis Kompetensi. Bandung: PT. Remaja Rosdakarya.

Nuh, Mohammad. 2013. Kurikulum 2013 (Opini). Jakarta: Kompas Edisi 7 Maret 2013.

Puskur Balitbang. 2001. “Kurikulum Berbasis Kompetensi Mata Pelajaran Bahasa Indunesia Sekolah Menengah Umum". Jakarta: Balitbang Depdiknas.

Ruwanto, Bambang. 2013. "Buku Teks Kurikulum 2013" (Artikel). Yogyakarta: Kedaulatan Rakyat. 